\title{
National Professional Standard and Teachers' Performance: A Cross-Sectional Survey of Punjab
}

* Sarfraz Ahmad, PhD Scholar

** Dr. Ziarab Mahmood, Assistant Professor

*** Dr. Muhammad Ishaq, Assistant Professor

\begin{abstract}
The purpose of this study was to analyze performance of teachers of public sector on the base of code of conduct. The objectives of the study were to analyze knowledge, disposition and performance of secondary school teachers of code of conduct as per National Professional Standards i.e code of conduct. It was proposed that teachers of selected schools have significant level of knowledge, disposition \& performance of code of conduct. Out of 19,265 secondary school teachers of province Punjab, 401 teachers were selected randomly. Out of 3,601 headmasters of secondary schools 222 headmasters were selected randomly. Two questionnaires were used for collection of data from selected secondary school teachers \& headmasters of secondary schools. Data was collected from selected districts with the help of association of scholars. Data was analyzed by applying Chi-Square with SPSS software. Findings showed that secondary schools teachers have adequate knowledge, disposition and performance about code of conduct but they don't keep themselves update professionally by recent educational activities. School education department should launch training programs about knowledge, teachers should improve disposition and perform their duties well regarding National Professional Standards (NPS) i.e code of conduct.
\end{abstract}

Keywords: Secondary School Teacher (SST), Knowledge, Disposition, Performance, Code of Introduction

Conduct, National Professional Standards (NPS)

Education is a teaching learning system aiming to socialize individual and effect on the socio-cultural fabric of society because significant structural changes are taking place in all aspects of life. A teacher is a responsible for teaching children according to guidelines in the light of national framework. In the twentieth century, the concept of education brought for getting employment. This concept gave base to skills in the field of education. Replacement of this idea brought many concepts about role of teacher with the passage of time. A twenty first century, education of children demands opportunities for the knowledgeable, ethical, aesthetic and skills development of children and the provision of a school environment that can constructively guide children in their more development. This century is also marked by developments as evidenced by industrialization and technological advancement for developed living standards (Szirmai, 2013; Shakir, 2011).

The worth of education depends on the value of teachers. Similarly, without teaching knowledge, disposition and skills quality of teachers is incredible. Without efficient teachers even in a superb education system is considered to be failed and on other hand skillful teachers can effectively dazed the flaws of education system. In fact, good teachers of any society are considered the uppermost academic and professional individual in the educational setup. There are three significant components among teachers which directly influenced on students' achievements. They have professional characteristics, teachers' performance and class room management. Each provides a unique way that instructors can recognize contribution they make (Singh, 2007: Moon, 2004).

Standard is a principal of propriety, quality, honesty and integrity, an accepted or approved example level of something of a school, system and country. Educational standards are the knowledge, disposition and performance. Teachers face at critical points in their educational career of

* Department of Education, Mohi-ud-Din Islamic University, AJ\&K

** Department of Education, Mohi-ud-Din Islamic University AJ\&K

*** Department of Education \& Director QEC Mohi-ud-Din Islamic University AJ\&K

Email: Muhammadishaq@ miu.edu.pk 
teaching. Professional Standards play role as a basis of educational reforms in the whole country as teachers. National policy makers respond to the call for a clear picture of desired student learning outcomes. It is a way to measure success of children in terms of these outcomes. Teachers play a main role in improving student learning outcomes by implementation and development of standards in the country (ETUCE, 2002).

There is increased internationally for assessment and accreditation of teacher's standards. In USA, first the American Association of Colleges for Teacher Education (A.A.C.T.E), accredited for teacher education programmes. After this, in 1954, the National Council for Accreditation of Teacher Education (N.C.A.T.E) was established and in 1997, the Teacher Education Accreditation Council (T.E.A.C) was established. In 2013, T.E.A.C and N.C.A.T.E were combined to make the Council for the Accreditation of Educator Preparation (C.A.E.P). For colleges and universities, National Council for Accreditation of Teacher Education (N.C.A.T.E) is the accrediting body that gives training to teachers to work in elementary and secondary schools. The N.C.A.T.E accreditation process goals to enhance that accredited institutions produce qualified, caring and competent teachers who can help all children learn. In Australia, the Australian Government gave funds the Australian Institute for Teaching and School Leadership (A.I.T.S.L) was established in 2010. While, A.I.T.S.L acts on behalf of all of Australia's Education Ministers state, territory and federal that it is nevertheless not a government department. The Australian Government, as represented by the Minister for School Education, Early Childhood and Youth, is the sole member of the company. In India, in 1993, The National Council for Teacher Education (N.C.T.E) was established, and in 1994, The National Assessment and Accreditation Council (N.A.A.C) was established, to assess and accredit Teacher Education Institutions (T.E.I's) in the whole country (Ducharme, R. \& Ducharme, K. 1998; CAEP, 2013b; AITSL, 2013; NAAC, 2007; Angus, D., 2001; NCATE 2001).

Professional standards for teachers were framed to analyze the performance of teachers. These professional standards delineate that what teachers require for enhancing teaching practices. UNECO Pakistan (2010) is cooperating to assess and implementing strengthen teacher training in the country. Although after $18^{\text {th }}$ amendment the power of Federal Ministry of Education has been shifted to all provinces. According to Government of Pakistan (2011), National professional standards for teachers can be implemented and exercised for all types of teachers.

According to Government of Pakistan (2009), Pakistan has main aim to contest with entire world through knowledge and by changing the barren endowment of its citizens into a rich fertile asset. Pakistan has wished to produce top most educational system from primary to higher education within the country. In this scenario only a competitive teacher can depict the world class education. A teacher is an individual of a society who prompt and pep up his students for prime learning. The quality learning is totally dependent on quality precept by professional teachers which are keenly enthusiastic and have sense of devotion for continuous professional ontogenesis in the various fields. In this regard, on $23^{\text {rd }}$ February, 2009 Government of Pakistan developed and designed ten professional standards for teachers.

According to Government of Pakistan (2009), after $18^{\text {th }}$ amendment act 2010 Federal Ministry of Education (MoE) does not exist now a day. Like other nations, on $23^{\text {rd }}$ Feb, 2009, with the help of Policy and Planning Wing Ministry of Education and with fiscal support of USAID, Government of Pakistan developed and designed national professional standards for teachers (N.P.S) for a better credible education. The names of these ten standards are given bellow. The National Professional Standards for Teachers have been designed with complete consensus of all provinces. These standards are: (i) "Subject Matter Knowledge", (ii) "Human Growth \& Development", (iii) "Knowledge of Islamic / Ethical Values/ Social Life Skills", (iv) "Instructional Planning \& Strategies", (v) "Assessment", (vi) "Learning Environment", (vii) "Effective communication \& proficient use of information communication technologies", (viii) "Collaboration \& Partnerships", (ix) "Continuous Professional Development \& Code of Conduct" and (x) "Teaching of English as a second/ foreign language (T.E.S.L/T.E.F.L)".

Professional Standards for Teachers help to equip and enrich the worth of teachers. All ten standards have their own value but code of conduct has a role of back bone to enhance the competence and commitment of all teachers. A code of conduct is a set of rules outlining the rule, norms, traditions and responsibilities or proper practices of a teacher, a school and department 
according to require standards. The teachers and non-teaching staff must follow professional code of conduct in their knowledge, behavior and performance that is available a written document. Teachers and non-teaching staff must follow ethics and professional code of conducts (N.A.C.T.E, 2009; N.P.S, 2009).

Objective: The objectives of the study were to analyze knowledge and understanding, disposition and performance of teachers' code of conduct that is one standard of National Professional Standards. i. To explore the understanding of secondary school teachers about code of conduct. ii. To check the disposition of secondary school teachers about code of conduct. iii. To analyze skills of secondary school teachers about code of conduct.

\section{Literature Review}

\section{Code of Conduct for Teachers}

There is a need to know the code of conduct for teachers, school and department manual to give targets for standard education. In which curriculum, co-curriculum activities, methods of teaching and management structure should be presented. Teaching is a moral universe that is guided by the departmental manual of education Government of the Punjab according to the aims of education. There is also need to be evaluated the teachers' knowledge according to department of educational calendar and manual to know the progress of the teachers and where is need for betterment that should be reported. All teachers should have opportunities for professional development in a five-year cyclic manner according to the national educational policies (Sockett, 2016; Government of the Punjab, 2004; Van Nuland, Khandelwal, 2006).

Teachers have key role to formulate the rules for students because teacher spend most of the time with students in classroom and school. Teachers' task is to teach and formulate rules for a classroom management plan to educate the development of an effective learning environment according to acceptable standards. In addition to adopting with posted rules, students are expected to show respect for self, parents, teachers and meet academic expectations. Secondary school teachers anticipate from their students to execute their teaching-learning process productively, efficiently, and effectively (Savage, 2009; Scarlett, 2015; Wiseman \& Hunt, (2013).

Teachers' primary responsibilities are not only teach the students in the class but also ensure that co-curricular activities, maintain registers and intellectual, religious, physical, moral and social welfare of the pupils under their charge. They follow a clear rules and regulations for the distribution of assigned workload. They implement notified practice teaching and research that made available by competent authority. The teachers should know the targets of quality, quantity and efficiency of the institution. The teachers should help to improve the quality of the institution. In-service training and seniors focus on update knowledge of teachers in identified deficiency areas, contextualizing education, community development, educational leadership and other areas of education for sustainable development (Dastoor-ul-Amal, 2004).

\section{Dispositions of Code of Conduct for Teachers}

Teachers' disposition are characterized as the values, duties, and professional ethics that impact practices toward students, families, partners, other groups and influence students' learning, inspiration, development and also the teacher's own professional development. Disposition are guided by believes and states of mind identified with qualities, for example trustworthiness, responsible, mindful, fairness and social justice. Each teacher, upon entering the profession, assumes a number of duties, one of which is to follow to a set of principles which defines professional code of conduct. These principles are reflected in the designed code of ethics, which sets forth to the education occupation and the public it serves standards of professional conduct and procedures for application. The teachers accept workload according to the code of conduct. Nonetheless, since 2009 the National Accreditation Council for Teacher Education (NACTE) has included professional disposition as a required evaluation of teacher training programmes accredited in the Pakistan. This confirms there is prevalent acceptance of the idea that teaching profession built around the world (NACTE 2009; NCATE, 2002).

Good discipline and performance are key basics for good education. Without an arranged atmosphere effective teaching-learning cannot take place. We expect and insist on the highest standards of performance in our school. The headmaster bring any serious rapport of discipline or any disruptive disposition to the attention of the parents concerned and a suitable course of action will be 
decided upon. The code of conduct clearly guides what behaviour is acceptable and what is not acceptable, i.e. the school rules (Collinson et al., 2009; Umoh \& Etuk, 2003; Umoh, 2006; Ma, X., 2004).

Provision for teachers to share experiences is an essential component of contemporary inservice design and professional code of conduct, even though a few systematic efforts to observe the impact of sharing on professional development have been reported. These standards were to create a central set of guidelines that could be used to develop principals through a shared vision for institutions in Punjab. Heads of all grade levels desired professional development that focuses on best practices to enhance instruction and assistance with developing quality assessments. Secondary school heads' desired additional professional development on creating a campus shared vision plan and ways to monitor and revise instruction to maximize accountability mandates. Professional development is vital for heads as they develop into sound instructional leaders who are continuously seeking ways to improve schools operations. Inspirational Motivation influence teachers' through communicating a shared vision and intellectual stimulation leaders actively engage participants in decision making for the shared vision (Plano, 2010; Nawab, 2011; Avery, 2015).

A teacher is a role model who you are guided and aspire. Anybody can be a role model, but the most significant role models just happen to be teachers. There are many reasons why students think of those in the teaching profession as role models. One of the main reasons is the desire to be regarded and remembered. We've all encountered great teachers in our lifetime that had a great impact on our lives. Whether it was discovering a specific course or learning a lesson of life. Teachers are the ones who help us learn and pave the way for a best future. If you desire about becoming a teacher, then you had best be ready to make a great and lasting impression. There are a few ways those in the profession of teaching can be role models for their pupils. Not only do students look at individuals other than their teachers as role models, but that the expression role model is too ambiguous in common usage to be sensibly understood in the first place. As a mentor, a teacher can technically be a role model, but so can someone perceived to be a hero or a personal champion. Therefore, one can be an effective mentor but still not be perceived as a role model (Bricheno \& Thornton, 2007; Martino, 2008; Schwartz, 2007).

Punctuality is sensitivity that manifests a realization, appreciation for the value of time and time commitments. An individual who practices punctuality habitually develops peace, calmness, tranquility and self-confidence. An individual who adheres to punctuality not only obtains achievement, satisfaction in life but also wins the respects of others in the society as duties discharged punctually help to mould the character of the individual. On the contrary unpunctuality dissipates vital timely opportunities that could have contributed to the growth of an individual. Also, it makes an individual tardy, dilatory, and unconcerned about the needs of others and develops in him/her anxiety, confusion, tension, frustration, and dissatisfaction. Punctuality reckons all appointments as commitments to be discharged dutifully in time. A teacher observes punctuality in school through observing the school academic schedules, completing time-bound schedules as finishing the study course in time well before the examinations, so that students will get time to revise, completing the evaluation process of examination papers of the students in time, keeping appointments and commitment made to students, management, colleagues and parents of the students and society; observing punctuality while undertaking social, cultural and sports programmes for the school; and in society being on time while attending to jobs, public functions and duties, honoring time commitments with respect to any work under taken (Makoto Ishii., 2010; Joshi, Kireet., 2002; Kalra \& Rajinder, 2003).

\section{Performance and Skills of Code of Conduct for Teachers}

A code of conduct is a set of written guidelines, produced by authorities or department of education, which details the set of recognized skills and professional standards of code of conduct to which all teachers of a profession must adhere (Fenning et al., 2004).

Teachers guide children according to goals provided by the National Curriculum Framework under the academic \& professional guidelines of the competent education department. They teach pupils according to the educational objectives, needs, abilities and attainment of potential of pupils assigned to his/ her supervision by the headmaster of School. Secondary school teaching is more than just marking books and setting tests. A teacher requires being motivated, approachable and 
knowledgeable of his / her subjects to engage with his /her pupils. Teachers are learners throughout their lives. The moment they stop bearing in mind themselves children, they stop and outdated to be teachers and even their performance become reverse gear because they forget the learned education of academic and professional. They need to keep on getting, updating and recycle knowledge of what they teach in class-rooms keeping up with the changing world. Winds of change is being blown from one era to another, from one decade to another, bring new concepts to old ideas and theories. The teachers should keep themselves to pace on this path of change to implement new or modified methods of teaching in order to suit the requirements of modern world. This is how teachers must develop or update themselves (Kramer, 2003; Hilferty, 2008; GoP, 2009; Nihan Demirkasunog lu., 2010; Creasy, 2015).

A syllabus is an outline for a term/semester/year that is either taking or teaching. In the typical context, which is for schooling, it is more detailed than that. The syllabi that are used to get had several parts e.g social, economic religious, science. The first was a brief introduction to the class and the scope of the material. Teachers then had a complete list of the topics that they would cover specific period of the month, quarter or year. We could also look at know the dates that any and all lessons, classes, and tests would be. They were written clearly on the syllabus, along with important information of the class. If teachers needed to know how to complete the courses, they guide the syllabus calendar (Ayers, 2001).

Ethical behavior is characterized by fairness, honesty and equity in inter-personal, academic and professional relationships. Ethical behavior respects the dignity, diversity and rights of students, class and examination. Acting of teachers in ways consistent with what individual, classroom, school and community usually think are good values. Ethical behavior tends to be good for teaching and involves demonstrating respect for key moral principles which consists of fairness, equality, honesty, dignity, diversity and individual rights. The fundamental principles of ethical behavior within the teachers focus on relationships among faculty, staff, administration, and children. This focus accepts that each profession has a Code of conduct that guides practice and professional service delivery and that the school provides additional principles on teaching activities for staff (Biggs \& Tang, 2007).

Hypotheses: $\mathrm{H}_{1}$ Secondary school teachers have significant level of knowledge about code of conduct. $\mathrm{H}_{2}$ Secondary school teachers have significant level of disposition about code of conduct. $\mathrm{H}_{3}$ Secondary school teachers have significant level of skill about code of conduct.

\section{Methodology}

Population is the teachers of Government secondary schools for boys in Punjab. There are 3,601 Government Boys Secondary Schools in rural \& urban areas this province. There are 19,265 secondary school teachers and 3601 headmasters in these schools (www.schools.punjab.edu.pk).

Simple random sampling technique was adopted. Out of 9 divisions, 9 districts were selected which were Gujranwala, Lahore, Faisalabad, Chakwal, Sargodha, Sahiwal, Multan, Bahawalpur and Dera Ghazi Khan. During selection of teacher, out of 19,265 teachers of 9 districts, Sample 623 (3.24\%) (401secondary school teachers and 222 headmasters) were taken randomly (Gay, 2012). Forty five teachers and twenty five headmasters were selected form each districts.

Questionnaire was used for collection of primary data. One five point rating scale was prepared for headmasters. One five point Likert type scale was designed for Secondary School Teachers. The twelve items of questionnaires comprised of three selected parameters i.e. secondary school teachers' knowledge, disposition and skills of national professional standard \# 9 e.g code of conduct.

Data from secondary schools was collected through personal visits from Lahore and Gujranwala districts with questionnaire. Selected schools were visited and questionnaires distributed after getting permission from principal. Questionnaires were gotten filled from teachers \& headmasters of remaining 7 districts with the help of district coordinators of Punjab Educational Research Scholars Association (PERSA).

\section{Data Analysis}

Collected was data and analyzed with SPSS software version 17. Filled questionnaires from headmasters and teachers were posted in software against defined codes. Chi-Square was calculated on recorded data. Results were interpreted with rules of statistics. 
Analysis of Knowledge

Table. 1: Table of Chi-Square of Knowledge.

\begin{tabular}{|c|c|c|c|c|c|c|c|c|c|c|}
\hline Items & Group & & SDA & DA & PA & A & SA & Total & $\chi^{2}$ & $P$ \\
\hline \multirow{4}{*}{$\begin{array}{l}\text { professional } \\
\text { code of conduct } \\
\text { for teachers }\end{array}$} & SSTs & $f$ & 14 & 87 & 42 & 191 & 67 & 401 & \multirow{4}{*}{39.018} & \multirow{4}{*}{0.000} \\
\hline & (401) & $(\%)$ & $3.49 \%$ & $21.69 \%$ & $10.42 \%$ & $47.63 \%$ & $16.71 \%$ & $100 \%$ & & \\
\hline & HTs & $f$ & 3 & 59 & 4 & 143 & 13 & 222 & & \\
\hline & (222) & (\%) & $1.35 \%$ & $26.57 \%$ & $1.80 \%$ & $64.41 \%$ & $5.9 \%$ & $100 \%$ & & \\
\hline \multirow{4}{*}{$\begin{array}{l}\text { Formulate } \\
\text { rules } \\
\text { students }\end{array}$} & SSTs & $f$ & 4 & 27 & 28 & 232 & 110 & 401 & \multirow{4}{*}{30.787} & \multirow{4}{*}{0.000} \\
\hline & (401) & $(\%)$ & $0.99 \%$ & $6.73 \%$ & $6.98 \%$ & $57.9 \%$ & $27.4 \%$ & $100 \%$ & & \\
\hline & HTs & $f$ & 1 & 30 & 13 & 155 & 23 & 222 & & \\
\hline & (222) & $(\%)$ & $0.45 \%$ & $13.51 \%$ & $5.85 \%$ & $69.8 \%$ & $10.4 \%$ & $100 \%$ & & \\
\hline \multirow{4}{*}{$\begin{array}{l}\text { Aware of } \\
\text { professional } \\
\text { responsibi-lities }\end{array}$} & SSTs & $f$ & 3 & 15 & 8 & 208 & 167 & 401 & \multirow{4}{*}{66.297} & \multirow{4}{*}{0.000} \\
\hline & (401) & $(\%)$ & $.74 \%$ & $3.74 \%$ & $1.99 \%$ & $51.87 \%$ & $41.64 \%$ & $100 \%$ & & \\
\hline & HTs & $f$ & 1 & 31 & 1 & 158 & 31 & 222 & & \\
\hline & (222) & (\%) & $.45 \%$ & $13.96 \%$ & $.45 \%$ & $71.17 \%$ & $13.96 \%$ & $100 \%$ & & \\
\hline \multirow{4}{*}{$\begin{array}{l}\text { Disciplinary } \\
\text { rules of school }\end{array}$} & SSTs & $f$ & 3 & 11 & 7 & 176 & 204 & 401 & \multirow{4}{*}{47.747} & \multirow{4}{*}{0.000} \\
\hline & (401) & $(\%)$ & $.75 \%$ & $2.74 \%$ & $1.74 \%$ & $43.89 \%$ & $50.87 \%$ & $100 \%$ & & \\
\hline & HTs & $f$ & 1 & 15 & 1 & 151 & 54 & 222 & & \\
\hline & (222) & $(\%)$ & $0.45 \%$ & $6.75 \%$ & $0.45 \%$ & $68.01 \%$ & $24.32 \%$ & $100 \%$ & & \\
\hline
\end{tabular}

Interpretations: Above table regarding first item of knowledge of secondary school teachers is showing that $64.34 \%(47.63 \%+16.71 \%)$ teachers and $70.3 \%(64.41 \%+5.9 \%)$ headmasters are agree \& strongly agree with $1^{\text {st }}$ statement or item. It is showing that most of teachers and headmasters are agree with this statement. Value of $p$ and chi-square $\left(p=0.000<0.05 \& \chi^{2}=39.018>9.49\right)$ are showing that this result is significant. It is concluded that most of SSTs know code of conduct for teachers. Value of frequency of agree \& strongly agree is showing that $85.3 \%(57.9 \%+27.4 \%)$ teachers and $80.2 \%(69.8 \%+10.4 \%)$ headmasters with $2^{\text {nd }}$ item of knowledge of code of conduct. Value of $\mathrm{p}$ and chi-square $\left(\mathrm{p}=0.000<0.05 \& \chi^{2}=30.787>9.49\right)$ is showing that this result is significant. It is concluded that SSTs formulate rules for students.

Table is showing that $93.51 \%(51.87 \%+41.64 \%)$ teachers and $85.13 \%(71.17 \%+13.96 \%)$ headmasters are agree \& strongly agree with $3^{\text {rd }}$ item. It is showing that most of teachers \& headmasters are agree $\&$ strongly agree. Value of $p$ and chi-square $\left(p=.000<0.05 \& \chi^{2}=66.297>9.49\right)$ are showing that this result is highly significant. So, it is concluded that SST is aware of his professional responsibilities. Table is showing that $94.76 \%(43.89 \%+50.87 \%)$ Teachers are agree \& strongly agree while $82.33 \%(68.01 \%+24.32 \%)$ headmasters are agree with $4^{\text {th }}$ item. Value of $\mathrm{p}$ and chi-square $\left(p=.000<0.05 \& \chi^{2}=47.747>9.49\right)$ are showing that this result is significant. It is concluded that SST knows disciplinary rules of his institution. Hence, on the basis of $p$ values of all questions, $1^{\text {st }}$ hypothesis is accepted that Secondary School Teachers have significant level of knowledge about code of conduct.

Analysis of Disposition.

Table. 2: Table of Chi-square of Disposition.

\begin{tabular}{|c|c|c|c|c|c|c|c|c|c|c|}
\hline \multirow{2}{*}{$\begin{array}{c}\text { Items } \\
\text { Knowledge }\end{array}$} & \multicolumn{2}{|c|}{ Group } & SDA & DA & PA & $\mathbf{A}$ & SA & Total & $\chi^{2}$ & $P$ \\
\hline & SSTs & F & 1 & 10 & 17 & 211 & 162 & 401 & & \\
\hline about the & (401) & (\%) & $0.25 \%$ & $2.49 \%$ & $4.24 \%$ & $52.61 \%$ & $40.40 \%$ & $75.00 \%$ & & \\
\hline $\begin{array}{l}\text { Code of } \\
\text { conduct is a }\end{array}$ & $\begin{array}{l}\text { HTs } \\
(222)\end{array}$ & $\mathrm{F}$ & 0 & 27 & 6 & 163 & 26 & 222 & 73.230 & 0.000 \\
\hline $\begin{array}{l}\text { source of } \\
\text { school } \\
\text { discipline }\end{array}$ & & $(\%)$ & $0.00 \%$ & $12.16 \%$ & $2.70 \%$ & $73.42 \%$ & $11.71 \%$ & $25.00 \%$ & & \\
\hline $\begin{array}{l}\text { Share } \\
\text { successful }\end{array}$ & $\begin{array}{l}\text { SSTs } \\
(401)\end{array}$ & $\mathrm{F}$ & 1 & 28 & 12 & 225 & 135 & 401 & 83.555 & 0.000 \\
\hline
\end{tabular}




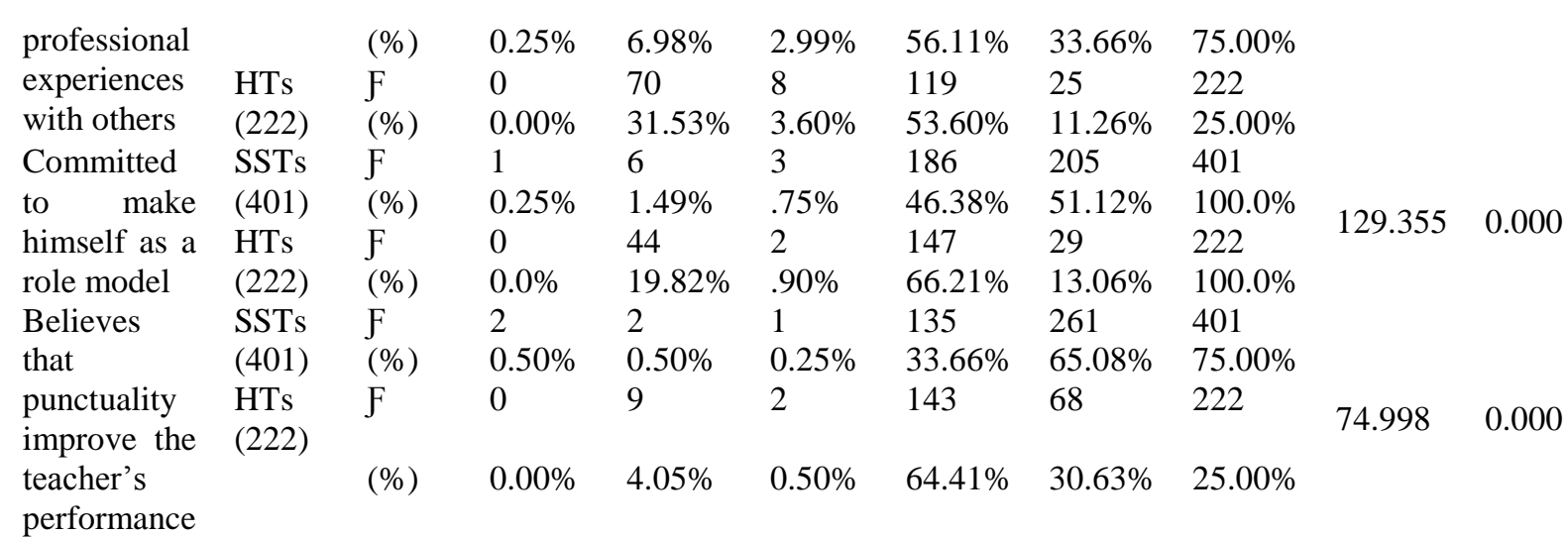

Interpretations: Table is showing that $93.01 \%(52.61 \%+40.40 \%)$ teachers and $85.13 \%$ $(73.42 \%+11.71 \%)$ headmasters are agree $\&$ strongly agree with $1^{\text {st }}$ item of disposition respectively. Value of $\mathrm{p}$ and chi-square $\left(0.000<0.05 \& \chi^{2}=73.230>9.49\right)$ is showing that this result is highly significant. It is accepted that teachers think the knowledge about the code of conduct is a source of school discipline. Analysis regarding second item in the above table is showing that $89.77 \%$ $(56.11 \%+33.66 \%)$ teachers and $64.86 \%(53.60 \%+11.26 \%)$ headmasters are agree \& strongly agree with $2^{\text {nd }}$ item respectively. It shows that most of respondents are agree with this question. Value of $\mathrm{p}$ and chi-square $\left(\mathrm{p}=0.000<0.05 \& \chi^{2}=83.555>9.49\right)$ is showing that this result is highly significant. So, it is accepted that secondary school teachers shares successful professional experiences with others.

Value of frequency of third item in the above table is showing that $97.5 \%(46.38 \%+51.12 \%)$ teachers while $79.27 \%(66.21 \%+13.06 \%)$ headmasters are agree \& strongly agree with $3^{\text {rd }}$ question respectively. Value of $P$ value and chi-square $\left(0.000<0.05 \& \chi^{2}=129.355>9.49\right)$ are showing that this result is also highly significant. So, it is declared that secondary school teachers are committed to make themselves as a role model. Table is showing $98.74 \%(33.66 \%+65.08 \%)$ teachers and $95.04 \%$ $(64.41 \%+30.63 \%)$ headmasters are agree \& strongly agree with this item. It is showing that most of respondents are agree with last questions of disposition. Value of $\mathrm{p}$ and chi-square $(\mathrm{p}=0.000<0.05 \&$ $\left.\chi^{2}=74.998>9.49\right)$ are showing that this result is highly significant. Thus, it is also accepted that secondary school teachers believe that punctuality improves the teachers' performance. Hence, on the basis of results, $2^{\text {nd }}$ hypothesis is accepted that secondary school teachers have significant level of disposition about code of conduct.

Analysis of Performance:

Table. 3: Table of Chi-square of Skills

\begin{tabular}{|c|c|c|c|c|c|c|c|c|c|c|}
\hline \multirow{5}{*}{$\begin{array}{l}\text { Items } \\
\text { Handle duties } \\
\text { to the best of } \\
\text { abilities }\end{array}$} & \multicolumn{2}{|c|}{ Group } & SDA & DA & PA & $\mathbf{A}$ & SA & Total & $\chi^{2}$ & $P$ \\
\hline & SSTs & $f$ & 1 & 1 & 5 & 174 & 220 & 401 & \multirow{4}{*}{126.107} & \multirow{4}{*}{0.000} \\
\hline & (401) & $(\%)$ & $0.25 \%$ & $0.25 \%$ & $1.25 \%$ & $43.39 \%$ & $54.86 \%$ & $75.00 \%$ & & \\
\hline & HTs & $f$ & 2 & 28 & 1 & 158 & 33 & 222 & & \\
\hline & (222) & $(\%)$ & $0.90 \%$ & $12.61 \%$ & $0.45 \%$ & $71.17 \%$ & $14.86 \%$ & $25.00 \%$ & & \\
\hline \multirow{4}{*}{$\begin{array}{l}\text { Keep himself } \\
\text { update } \\
\text { professionally }\end{array}$} & $\begin{array}{l}\text { SSTs } \\
(401)\end{array}$ & $f$ & 2 & 65 & 11 & 198 & 125 & 401 & \multirow{4}{*}{176.110} & \multirow{4}{*}{0.000} \\
\hline & & $(\%)$ & $0.50 \%$ & $16.20 \%$ & $2.74 \%$ & $49.37 \%$ & $31.17 \%$ & $75.00 \%$ & & \\
\hline & HTs & $f$ & 4 & 149 & 7 & 45 & 17 & 222 & & \\
\hline & (222) & $(\%)$ & $1.80 \%$ & $67.11 \%$ & $3.15 \%$ & $20.27 \%$ & $7.65 \%$ & $25.00 \%$ & & \\
\hline \multirow{4}{*}{$\begin{array}{l}\text { Complete } \\
\text { class syllabus } \\
\text { in time }\end{array}$} & SSTs & $f$ & 1 & 4 & 2 & 176 & 218 & 401 & \multirow{4}{*}{61.672} & \multirow{4}{*}{0.000} \\
\hline & (401) & $(\%)$ & $0.25 \%$ & $0.99 \%$ & $0.50 \%$ & $43.89 \%$ & $54.36 \%$ & $75.00 \%$ & & \\
\hline & HTs & $f$ & 2 & 8 & 0 & 161 & 51 & 222 & & \\
\hline & (222) & $(\%)$ & $.90 \%$ & $3.60 \%$ & $0.00 \%$ & $72.52 \%$ & $22.97 \%$ & $25.00 \%$ & & \\
\hline \multirow{4}{*}{$\begin{array}{l}\text { Maintain } \\
\text { ethical } \\
\text { behaviors in } \\
\text { teaching and } \\
\text { assessment }\end{array}$} & SSTs & $f$ & 3 & 2 & 1 & 176 & 219 & 401 & \multirow{4}{*}{74.726} & \multirow{4}{*}{0.000} \\
\hline & (401) & $(\%)$ & $0.75 \%$ & $0.50 \%$ & $0.25 \%$ & $43.89 \%$ & $54.61 \%$ & $75.00 \%$ & & \\
\hline & HTs & $f$ & 2 & 25 & 5 & 130 & 60 & 222 & & \\
\hline & (222) & $(\%)$ & $0.90 \%$ & $11.26 \%$ & $2.25 \%$ & $58.55 \%$ & $27.02 \%$ & $25.00 \%$ & & \\
\hline
\end{tabular}

Interpretations: Percentage of frequency in the above table regarding first item of skills of secondary school teachers is showing that $98.25 \%(43.39 \%+54.86 \%)$ teachers and $86.03 \%(71.17 \%+14.86 \%)$ head teachers are agree $\&$ strongly agree with $1^{\text {st }}$ item of performance about code of conduct. Value of 
$\mathrm{p}$ and chi-square $\left(\mathrm{p}=.000<0.05 \& \chi^{2}=126.107>9.49\right)$ is showing that this result is highly significant. It shows that most of the teachers are handling their duties to the best of their abilities.

Percentage of frequency regarding the second item in the above table, $80.54 \%$ $(49.37 \%+31.17 \%)$ teachers are showing that most of teachers are agree $\&$ strongly agree with $2^{\text {nd }}$ item. Percentage of frequency is showing that $68.91 \%(1.80 \%+67.11 \%)$ of headmasters are disagree $\&$ strongly disagree. Value of $p$ and chi-square $\left(p=.000<0.05 \& \chi^{2}=176.110>9.49\right)$ are showing that this result is highly significant. Due to rating of headmasters, it shows that teachers do not keep themselves update professionally by recent educational activities.

Percentage of frequency of $3^{\text {rd }}$ item is showing that $98.25 \%(43.89 \%+54.36 \%)$ teachers and $95.49 \%(72.52 \%+22.97 \%)$ headmasters are agree with item of syllabus. Value of $\mathrm{p}$ and chi-square $\left(p=.000<0.05 \& \chi^{2}=61.672>9.49\right)$ is showing that this result is significant. Thus, it is accepted that Teachers complete class syllabus in time.

Value of last item in the table is showing that $98.5 \%(43.89 \%+54.61 \%)$ teaches are agree $\&$ strongly agree and $85.57 \%(58.55 \%+27.02 \%)$ headmasters are agree \& strongly agree with last item that teachers maintain ethical behaviors in teaching and assessment. Value of $\mathrm{p}$ and chi-square $(\mathrm{p}=.000<0.05 \& 74.726>9.49)$ is showing that this result is significant. On the basis of results, $3^{\text {rd }}$ hypothesis was accepted. Overall Secondary school teachers have significant level of skills about code of conduct. But they don't keep themselves update professionally by recent educational activities.

\section{Discussion}

The research studies explored the ways in which continuing professional development and professional code of conduct are being evaluated the teachers at different level. Harris et al. (2006) focused upon the extent to which schools are gauging the impact of continuing professional development (CPD) and professional code of conduct particularly at the classroom level. They concluded that the impact of code of conduct on student learning remains significantly underevaluated. They suggested that schools should mentor effectively and train teachers in order to evaluate the effect of code of conduct. After that Shakir \& Adeeb (2011) conducted research on performance of secondary school teachers in Punjab. They concluded that more than half of the teachers have poor knowledge about continuous professional development and code of conduct and even they do not recognize the importance of teaching skills. Results of this study have also showed that secondary school teachers have knowledge of code of conduct, aware of their professional responsibilities; know how to formulate rules for students and the disciplinary rules of their schools. The teachers improve disposition level in sources of school discipline, share successful experiences with others, act as a role model, and adopt punctuality according to standards. The teachers perform their duties well, complete syllabus in time and behave ethically with students and other stakeholders but they don't update professionally.

\section{Conclusion}

It is concluded that most of secondary school teachers know about professional code of conduct. They formulate rules for students. They are aware of their professional responsibilities. They know disciplinary rules of their schools. They think that the knowledge about the code of conduct is a source of school discipline. They share successful professional experiences with colleagues. They are committed to make themselves as a role model. They believe that punctuality improves the teachers' performance. While it is concluded that teachers do not keep themselves update professionally by recent educational activities. They complete class syllabus in time. They maintain ethical behavior in teaching \& assessment. Secondary school teachers have significant level of knowledge, disposition and skills about code of conduct. But they don't keep themselves update professionally by recent educational activities. The knowledge, disposition and performance about code of conduct are very important for a teacher because code of conduct is necessary for all teachers to ensure ethical decision making even in difficult situation. School education department should arrange training programmes for the teachers to enrich them understanding, change in disposition and improve different skills according to national professional standards especially code of conduct.

\section{Recommendations}

1. School education department should introduce the extensive plans for all teachers and headmasters to create awareness to embrace national professional standards for teachers in 
teaching at district and tehsil level.

2. To develop a code of conduct approved by the Ministry of Education and adopted by teachers, to prepare training programmes for teachers. The department should design online programmes of educational supervision of code of conduct and to create an atmosphere of teachers, headmasters, and master trainers.

3. Findings showed that teachers do not keep themselves update professionally by recent educational activities. The department should facilitate that secondary school teachers have knowledge of code of conduct, aware of their professional responsibilities, know how to formulate rules for students and have knowledge of the disciplinary rules of their schools.

4. Secondary school teachers should improve disposition level in sources of school discipline, share successful experiences with others, be a role model, and adopt punctuality according to standards.

5. Secondary school teachers should perform their duties well, update professionally that is a most weak area, complete syllabus in time and behave ethically with students and other stakeholders.

6. The department should arrange training programmes regularly utilizing highly qualified teachers for the teachers to enrich them to promote understanding, change in disposition and

References improve different skills about code of conduct as per national professional standards.

AITSL (2013). AITSL Annual Report 2012-2013. Canberra: The Australian Institute for Teaching and School Leadership.

Angus, D. (2001). Professionalism and the public good: A brief history of teacher certification. Washington, DC: Fordham Institute.

Avery, M. E. (2015). The Gendering of Outdoor Recreation: Women's Experiences on Their Path to Leadership (Doctoral dissertation, Texas State University).

Ayers, W. (2001).To teach: The journey of a teacher ( $2^{\text {nd }}$ ed). New York, NY: Teachers College Press.

Biggs, J., \& Tang, C. (2007). Teaching for Quality Learning at University. The Society for Research into Higher Education.

Bricheno, P. \& Thornton, M. (2007). Role model, hero, or champion? Children's views concerning role models. Educational Research, 49(4), 383-396.

CAEP (2013). Annual Report to the public, the states, policymakers, and the education profession. Washington, DC: Council for the Accreditation of Educator Preparation.

Collinson, V., Kozina, E., Lin, Y.K., \& Ling, L. (2009). Professional Development for Teachers: A world of change. European Journal of Teacher Education, 32(1), 1-10.

Creasy, K. (2015). Defining Professionalism in Teacher Education Programs; Journal of Education \& Social Policy Vol. 2, No. 2, 23.

Ducharme, R. \& Ducharme, K. (1998). The American Association of Colleges for Teacher Education: A History, AACTE Publications, One DuPont Circle, Suite 610, Washington, DC 200361186.

ETUCE, (2002) Quality in Education Presentation of Etuce's Work 1995-2001. Brussels Etuce.

Fenning, Theodos, Benner, \& Bohanon-Edmonson (2004). Integrating proactive discipline practices into codes of conduct. Journal of School Violence, 45-61.

Gay, L. R. (2012). Educational Research: Competencies for analysis and application. London (10 ${ }^{\text {th }}$ Ed): Merrill Publishing Company.

Government of Pakistan (2009). National Educational Policy 2009. Islamabad: Ministry of Education.

Government of Pakistan, (2009). National standards for accreditation of teacher education programs, National accreditation council for teacher education. Islamabad: Ministry of Education; Higher Education Commission; Academicians and Representatives of Provincial Government.

Government of the Punjab. (2004). Dastoor-ul-Amal, Elementary, Secondary \& Higher Secondary. Lahore: A. H. Printers. 
Harris, A., Day, C., Goodall, J., \& Lindsay, G. (2006).What difference does it Make? Evaluating the impact of continuing professional development in schools. Scottish Educational Review, 9199.

Hilferty, F. (2008). Teacher professionalism and cultural diversity: skills, knowledge, and values for a changing Australia. The Australian Educational Researcher, 35930, 53-70.

Joshi, Kireet., (2002). Philosophy of Value-Oriented Education Theory and Practice. New Delhi: ICPR.

Kalra, Rajinder M., (2003). Value-Oriented Education in Schools-Theory and Practice New Delhi: Shipra Publications.

Krammer, P.A. (2003). The ABC's of professionalism. Kappa Delta Pi Record, 40, 22-25. Retrieved from Eric database. (EJ787753).

Ma, X., \& Willms, J. D. (2004). School disciplinary climate: Characteristics and effects on eighth grade achievement. Alberta Journal of Educational Research, 50, 169-188.

Makoto Ishii., (2010). Implementing Character Education at Public Schools, Focusing on Satya Sai Education in Human Values: A Case Study of Satya Sai School, Leicester, U. K., and India. Ph.D.; Saybrook University. San Francisco, California. In Proquest Dissertations and Theses, Global.

Martino, W.J. (2008). Male teachers as role models: addressing issues of masculinity, pedagogy, and the re-masculinization of schooling. Curriculum Inquiry, 38(2), 189-223.

Moon, J. (2004). A Handbook of Reflective and Experiential Learning: Theory and Practice. London: Routledge Falmer.

NAAC (2007). Manual for Self - appraisal of Teacher Education Institutions. Bangalore, India: National Assessment and Accreditation Council.

National Accreditation Council for Teacher Education. (2009). National Standards for Accreditation of Teacher Education Programs (NACTE). Islamabad: Higher Education Commission.

National Council for Accreditation of Teacher Education. 2001. Professional Standards for the Accreditation of Schools, Colleges, and Departments of Education. Washington, DC: National Council for Accreditation of Teacher Educationnia Standards for the Teaching Profession (2009).

Nawab, A. (2011). Exploring leadership practices in the rural context of a developing country. International Journal of Academic Research in Business and Social Sciences, 1(3), 181-189. Retrieved from https:// www.hrmars.com.

Nihan Demirkasimog lu. (2010). Defining Teacher Professionals from different perspectives. Prodedia Social and Behavioral Sciences, 9, 2047-2051.

Plano Clark, V. L. \& Creswell, J. W. (2010). Understanding Research: A Consumer's Guide. Upper Saddle River, NJ: Pearson Education, Inc.

Punjab Educational Research Scholars Association (2020). An Association of M. Phil \& Ph. D Teachers. Research Center, Lahore.

Safia, B. (2005). Evaluation study of the Competencies of Secondary School Teachers in Punjab. Ph.D. Thesis, Institute of Education and Research, University of Arid Agriculture Rawalpindi, Published by Higher Education Commission Pakistan.

Savage, T. \& Savage, M. (2009). Successful classroom management and discipline: Teaching selfcontrol and responsibility (3rd ed.). Thousand Oaks, CA: Sage.

Scarlett, G. (2015). The SAGE encyclopedia of classroom management. Thousand Oaks, CA: Sage.

Schwartz, M.J. (2007). The modeling of moral character for teachers: behaviors, characteristics, and disposition that may be taught. Journal of Research in Character Education, 5(1), 1-28.

Shakir, M., \& Adeeb, M.A. (2011). Quality Teaching: Evaluating Teachers' Professional Code of Conduct and Practices. International Journal of Learning \& Development, 1 (2): 84-91.

Shakir, M. Hussain, I, Zaffar J.M. (2011). Are the teachers on track? An evaluation of secondary school teachers' subject knowledge competency. International Journal of Management Research and Emerging Sciences, 74-85

Singh, S. (2007). Changes in literacy beliefs and practices of a kindergarten teacher: A three-year longitudinal study. Unpublished dissertation, University of Illinois, Urbana-Champaign.

Sockett, H. (2016). Teaching in the moral universe. [Unpublished paper]. 
Szirmai A, Naudé W, Alcorta L. (Eds.) 2013. Pathways to Industrialization in the Twenty-First Century New Challenges and Emerging Paradigms. Oxford: Oxford University Press.

Umoh, M., \& Etuk, L.A. (2003). Principles of Curriculum Development in Agricultural Education. Abuja- Nigeria. Hill-Alex Ventures.

Umoh, A. M. (2006). Basic Psychology of Human Learning. Uyo-Nigeria.

UNESCO. (2008). Good Practices and International Trends of Teacher Accreditation and Secondary School Teacher. (Unpublished Master Thesis). Institute of Education and Research.

UNESCO.(2008).Good Practices and International Trends of Teacher Accreditation. What Makes It Special? Journal of teacher education, 59(5), 389-407.

Wiseman, D., \& Hunt, G. (2013). Best practice in motivation and management in the classroom (3rd ed.). Springfield, IL: Charles C. Thomas. www.schools.punjab.edu.pk 